\title{
Study of land suitability for rubber and cashew in the derived savanna zone of Edo State, Nigeria
}

\author{
Lucky Agbogun*, Aigboghosa Samson Umweni, Henry Onomolieghe Kadiri, and Faith Ehinomhen \\ Okunsebor \\ Department of Soil Science and Land Management, Faculty of Agriculture, University of Benin \\ P.M.B 1154, Ugbowo Lagos Rd, Benin City, Edo State, Nigeria \\ *Corresponding author: agbogunlucky@gmail.com
}

\section{Article Info}

Received : $14^{\text {th }}$ April 2021

Revised : $12^{\text {th }}$ July 2021

Accepted: $23^{\text {rd }}$ September 2021

Keywords:

Evaluation, mapping units, pedons, suitability

\begin{abstract}
This study attempted to assess the soil suitability in the derived savanna zone of Edo State, Nigeria for the cultivation of some tree crops. The research specifically aimed to evaluate soil suitability for cashew and rubber supported by suitability maps for both crops. In terms of land suitability evaluation, mapping units 1 and 2 , with an area coverage of 27.4 ha of the entire research area ( $100 \mathrm{ha}$ ) were found to be marginally suitable (S3) for rubber cultivation but moderately suitable (S2) for cashew. Mapping unit 3, with area coverage of 38 ha was found to be currently not suitable (N1) for rubber but marginally suitable (S3) for cashew cultivation. Mapping unit 4 representing area coverage of 34.7 ha was found to be permanently not suitable (N2) for rubber cultivation but marginally suitable (S3) for cashew. Thus, technically, rubber can only be cultivated in that land at marginal level with an expected productivity of 27.4 ha (27.4\%). Cashew can be cultivated at moderate and marginal levels with an expected yield of 27.4 ha $(27.4 \%)$ and 72.6 ha $(72.6 \%)$, respectively, of the total land area. Thus, the preferred crop for the studied is cashew. It is recommended that for any significant investment in cultivation of this crop, the priority is the moderate levels with an expected productivity of 27.4 ha or $27.4 \%$ of total land area.
\end{abstract}

\section{INTRODUCTION}

Soil is a large part of the natural medium that generates its properties after a long and slow changes reaching equilibrium with environmental and climatic conditions. Nevertheless, ever since the first human population shifted from hunting and gathering to commercial farming and herding, the soil has undergone intensive use. Irrational land use by humans has transpired over the years, with no purpose other than seeking the most maximum yield out of each type of land use. Consequently, the soil has intensely degraded. Hence, the only solution to stop this depleting trend is to establish regulated land use pattern that is, to use each soil type in a way that best suits its characteristics and to programme its management for minimal degradation. This is precisely is the final aim of land evaluation, in which this study is all about.

Land suitability assessment is an applied classification system that evaluates the capacity of the soil for its optimal usethat is, to derive maximum benefits with minimum degradation. This can be defined, according to Rossiter and Van Wambake (1997), as any method to explain or predict the use potential of land. Land evaluation is a process of estimating the potential of land for alternative types of use (Dent and Young, 1981). According to Food and Agriculture Organization (1976), land suitability is the process of assessing the performance of land when the land is used for specified purposes.

Conducting a land evaluation involves the inclusion of a number of reasons including soil properties, the ways in which soils react to various farming systems,

How to cite: Agbogun, L., Umweni, A.S., Kadiri, H.O., and Okunsebor, F.E. (2021). Study of land suitability for rubber and cashew in the derived savanna zone of Edo State, Nigeria. Ilmu Pertanian (Agricultural Science), 6(3), pp. 156-162. 
variations in climate, topography, geology and geomorphology (Peder, 2001). The results of a land evaluation exercise, therefore, serve as the basis for decision making by land use planners and other decision makers who have an influence on land use in a given region (Rossiter, 2001). Despite the importance of land evaluation stated above, some of the soils of Uzanu community in Edo State have not been evaluated for cashew and rubber production to boost the economic value of these two tree crops amongst the inhabitants of the community. The objectives of this work were to carry out suitability assessment for the production of rubber and cashew and to facilitate the transfer of knowledge related to improved agricultural practices carried out on similar soils elsewhere.

\section{MATERIALS AND METHODS}

\section{Site area}

This research was carried out in a farm land close to Uzanu community in Edo North, Nigeria. The site location ranged from Latitude $07^{\circ} 11^{\prime} 41.3^{\prime \prime} \mathrm{N}$ and Longitude $006^{\circ} 37^{\prime} 40.6^{\prime \prime} \mathrm{E}$ to Latitude $07^{\circ} 11^{\prime} 44.8^{\prime \prime} \mathrm{N}$ and Longitude $006^{\circ} 37^{\prime} 37.2^{\prime \prime} \mathrm{E}$. The site is defined by PEG 1 to PEG 8 appropriately georeferenced as in the attached location map of 100 ha (Figure 1a). Figure $1 \mathrm{~b}$ and $1 \mathrm{c}$ also define aerial views generated from LandSAT and Google imageries of the same area.

The site location is known for its rainfall of $1,200 \mathrm{~mm}$ per year to $1,500 \mathrm{~mm}$ per year, an average temperature of $27^{\circ} \mathrm{C}$ to $32{ }^{\circ} \mathrm{C}$, and annual relative humidity of $30.5 \%$ to $94.0 \%$ (Weppa Wanno Farms, 2013). The area lies within the northern belt of derived savanna-forest transition. The dry season begins in November and ends in March. The rainfall pattern is bimodal with peaks in July and August. However, there is a short spell in mid-August accompanied by few thunder storms (Remison, 2005).

The soils are derived from Agwu-Nkporo shale Group. The topography of the site has a gradual slope of $2 \%$ to $6 \%$ and rock outcrops visible in some parts of the study area. The vegetation includes riparian forest along the stream course, scattered trees, oil palm, and some old and new farms cultivated for sweet potatoes, rice, yam, cassava, etc. Moreover, the series of rock outcrops visible in some areas may have caused the sparsely populated vegetation in the area along with their roots to spread on the soil surface, and this is an indication that vegetation increases as soil depth increases in the area.

\section{Field Studies}

The perimeter map of the land was used as a base map. A field survey was carried out in a selected area of 100 hausing a rigid grid system survey method with traverses made at a distance of $100 \mathrm{~m}$ on a predetermined baseline with tracks running in horizontal and vertical directions perpendicular to each other, amounting to a total of 10 transects. Auger points were placed at $100 \mathrm{~m}$ interval along the transects, giving a total of 84 auger/examination points at a depth of $0 \mathrm{~cm}$ to $120 \mathrm{~cm}$ in all cases. Auger samples were also described looking at the morphological makeup in the field. Some areas with similar features
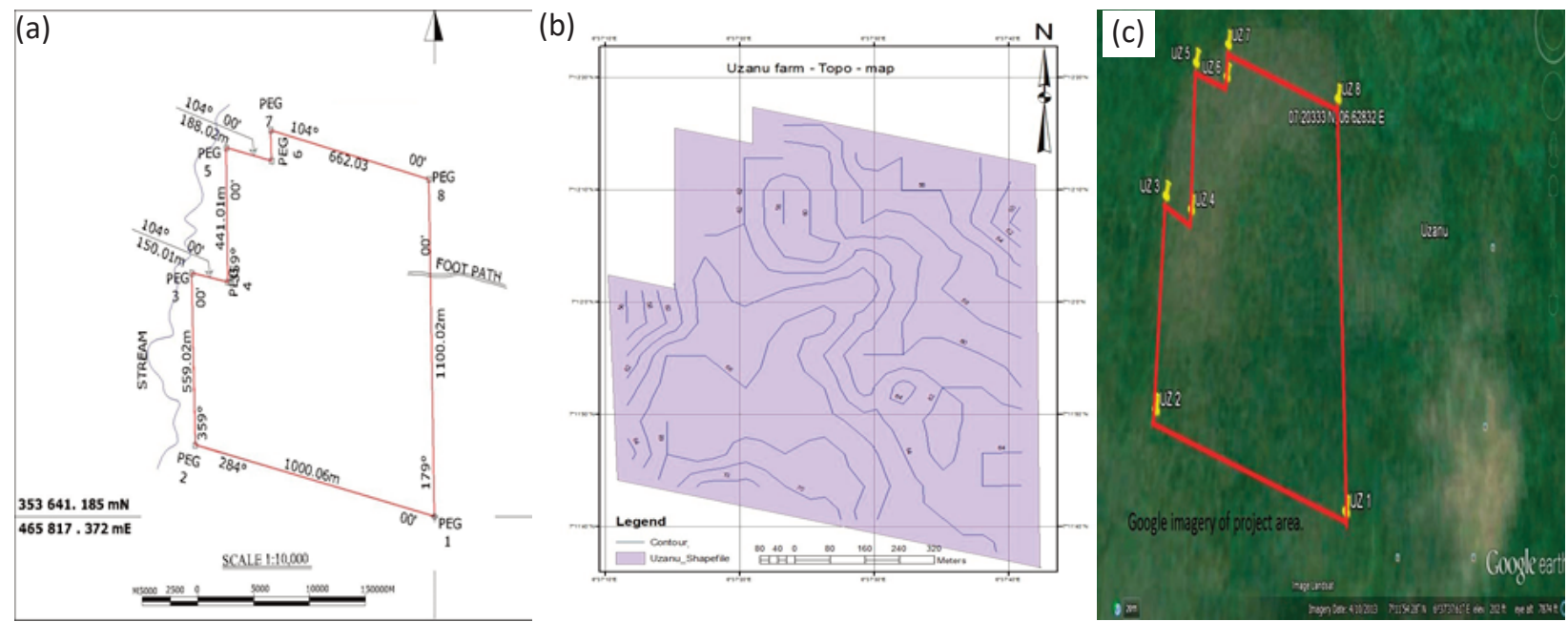

Figure 1. Location map of the 100 hectare land in Edo State (a), topographical map of the study area (b), google imagery of the study area (c) 
and characteristics such as texture and topographic positions on the landscape were grouped to produce the various soil mapping units. Four mapping units were eventually delineated. Profile pits of $3 \mathrm{fts} \times 3 \mathrm{fts}$ $\times 3 \mathrm{fts}$ dimension were dug at representative points in each mapping unit, described according to Food and Agriculture Organization (1976), and identified horizons were sampled accordingly.

\section{Laboratory studies}

The soil samples collected from each layer of the profile were air-dried and passed through a $2 \mathrm{~mm}$ sieve. The sieved samples were then studied for some physical and chemical properties. Particle size distribution was determined in the laboratory following hydrometer method (Gee and Or, 2002). Phosphorus availability of the soil was analysed according to Bray-1 methodology (Olsen and Sommers, 1982). Soil pH was tested using glass electrode $\mathrm{pH}$ meter in soil (Mclean, 1982). Exchangeable Bases ( $\mathrm{Na}$, $\mathrm{K}, \mathrm{Ca}$ and $\mathrm{Mg}$ ) were observed with neutral normal ammonium acetate $\left(\mathrm{NH}_{4} \mathrm{OAC}\right.$ at $\left.\mathrm{pH} 7.0\right)$ (Thomas, 1982).

otal Nitrogen was analysed using the method of Bremner (1996). Exchangeable acidity determination was done by titration methodology (Anderson and Ingram, 1993). Walkley Black method was used to assess organic carbon (Page, 1982). Effective Cation Exchange Capacity (ECEC) was determined from the addition of exchangeable bases and exchangeable acidity (Tan, 1996). Calculation of Base Saturation was performed by dividing the sum of exchangeable bases ( $\mathrm{Na}, \mathrm{K}, \mathrm{Ca}$ and $\mathrm{Mg}$ ) by ECEC and multiplying the results by 100 .

\section{Soil classification}

Soil classification was done using the procedure by USDA soil taxonomy (Soil Survey Staff, 2014), and series was done locally.

\section{Land suitability evaluation}

This was carried out according to the guidelines provided by Behzad et al. (2013), Djaenudin et al. (2003), Tyagi (2003), Sys (1985), and Food and Agriculture Organization (1976) for land suitability evaluation for rain fed agriculture. Suitability classes were obtained by comparing land qualities and land use requirement based on previous approach. The suitability class (aggregate suitability) is that indicated by the list property of that mapping unit. This is in accordance with the principle of the law of minimum (Food and Agriculture Organization, 1984).

\section{RESULTS AND DISCUSSION}

The results of physical and chemical analysis of the soils in the area are presented in Table 1 and Table 2. Table 1 indicate that $\mathrm{pH}\left(\mathrm{H}_{2} \mathrm{O}\right)$ range was 3.9 to 4.4 from top to last horizon of pedon 1 and decreased from top to bottom for pedon 2, which is in line with the findings of Tomczyk et al. (2020). It increased from top to bottom (4.5 to 4.7) in pedon 3 and was same (4.6) from top to bottom for pedon 4. Organic carbon was $16.28 \mathrm{~g} . \mathrm{kg}^{-1}$ to $2.98 \mathrm{~g} . \mathrm{kg}^{-1}$ for pedon 1 and decreased from top to last horizon for pedons 2 to 4 . The low organic carbon content in some horizons is in agreement with the findings of Peter and Umweni (2021). Total nitrogen was 1.29 g. $\mathrm{kg}^{-1}$ to $0.70 \mathrm{~g} . \mathrm{kg}^{-1}$ from first to last horizon for pedon 1 and decreased from top to bottom for pedons 2 to 4 . Total nitrogen was moderate, ranging from $1.29 \%$ to $0.70 \%, 0.53 \%$ to $0.60 \%, 0.56 \%$ to 0.23 $\%$ and $0.77 \%$ to $0.71 \%$, respectively. This is likely be as a result of the moderate rainfall amount in the study area (Olowojoba et al., 2016).

Available phosphorus was $1.09 \mathrm{mg} \cdot \mathrm{kg}^{-1}, 5.28$ $\mathrm{mg} \cdot \mathrm{kg}^{-1}$, and $3.46 \mathrm{mg} \cdot \mathrm{kg}^{-1}$ for pedon 1 and decreased from top layer to bottom for pedons 2 to 4 . Sodium was irregular for pedons 1, 2, and 3 but decreased in value from top to bottom for pedon 4. Potassium was irregular for pedon 1 and 2 but increased in value from top to bottom for pedons 3 and 4 . Calcium was irregular for pedon 1, 2, and 3 but decreased from 1.03 cmol. $\mathrm{kg}^{-1}$ to $0.59 \mathrm{cmol}^{\mathrm{kg}}{ }^{-1}$ for pedon 4 . Magnesium was irregular for pedon 1 but decreased in value for pedon 2 and 3 , and increased in value for pedon 4 . Aluminum was irregular for pedons 1, 2, and 3 but increased from top to bottom for pedon 4 . Hydrogen decreased from 1.90 to 0.40 for pedon 1 , irregular for pedons 2 and 3 , and increased in value for pedon 4. Effective cation exchange capacity of soil (ECEC soil) was irregular for pedons 1,2 , and 3 but increased from $4.34 \mathrm{cmol}^{\mathrm{kg}}{ }^{-1}$ to $8.11 \mathrm{cmol}^{\mathrm{kg}}{ }^{-1}$ for pedon 4 . Effective cation exchange capacity of clay (ECEC clay) decreased from top to bottom for pedons 1, 2, and 3 but increased from $14.00 \mathrm{cmol} . \mathrm{kg}^{-1}$ to 18.86 $\mathrm{cmol} . \mathrm{kg}^{-1}$ for pedon 4. This is also in agreement with the findings of Olowojoba et al. (2016). Base saturation (BS) was irregular for pedons 1 and 3 but decreased from top to bottom for pedons 2 and 4 . 
Table 1. Chemical analytical results for profile samples

\begin{tabular}{|c|c|c|c|c|c|c|c|c|c|c|c|c|c|c|c|}
\hline $\begin{array}{l}\text { Pedon } \\
\text { ID }\end{array}$ & $\begin{array}{l}\text { Depth } \\
(\mathrm{cm})\end{array}$ & $\begin{array}{c}\mathrm{pH}(1: 1) \\
\mathrm{H}_{2} \mathrm{O}\end{array}$ & $\begin{array}{c}\text { EC } \\
\mu . \mathrm{cm}^{-1}\end{array}$ & $\begin{array}{l}\text { Org. C } \\
\left(\mathrm{g} \cdot \mathrm{kg}^{-1}\right)\end{array}$ & $\begin{array}{l}\text { Total N } \\
\left(\mathrm{g} \cdot \mathrm{kg}^{-1}\right)\end{array}$ & $\begin{array}{l}\text { Avail. P } \\
\left(\mathrm{mg} \mathrm{kg}^{-1}\right)\end{array}$ & $\mathrm{Ca}$ & $\mathrm{Mg}$ & K & $\mathrm{Na}$ & $\begin{array}{c}\mathrm{Al}^{3+} \\
\left(\mathrm{cmol} \cdot \mathrm{kg}^{-1}\right)\end{array}$ & $\mathrm{H}^{+}$ & $\operatorname{ECEC(S)}$ & $\begin{array}{l}\mathrm{ECEC}(\mathrm{C}) \\
\longrightarrow\end{array}$ & $\begin{array}{l}\text { BS } \\
(\%)\end{array}$ \\
\hline A & $0-10$ & 3.9 & 157.00 & 16.28 & 1.29 & 1.09 & 0.63 & 0.15 & 0.08 & 0.51 & 7.20 & 1.90 & 10.47 & 49.86 & 13.09 \\
\hline $\mathrm{Bt}_{1}$ & $10-30$ & 4.0 & 25.50 & 6.83 & 0.64 & 5.28 & 0.36 & 0.08 & 0.10 & 0.29 & 4.00 & 1.80 & 6.63 & 21.39 & 12.52 \\
\hline $\mathrm{Bt}_{2}$ & $30-56$ & 4.0 & 28.20 & 6.65 & 0.70 & 3.46 & 0.38 & 0.13 & 0.14 & 0.52 & 7.00 & 1.00 & 9.17 & 23.51 & 12.76 \\
\hline $\mathrm{C}$ & $\begin{array}{l}56- \\
106\end{array}$ & 4.4 & 21.40 & 2.98 & Trace & 0.00 & 0.50 & 0.21 & 0.08 & 0.53 & 8.40 & 0.40 & 10.12 & 21.53 & 13.04 \\
\hline A & $0-12$ & 4.9 & 63.00 & 5.05 & 0.53 & 2.73 & 1.09 & 0.82 & 0.15 & 0.33 & 1.80 & 0.40 & 4.59 & 18.36 & 52.07 \\
\hline$B w_{1}$ & $0-30$ & 4.6 & 16.40 & 7.44 & 0.51 & 2.28 & 0.61 & 0.49 & 0.07 & 0.27 & 1.80 & 0.70 & 3.94 & 10.65 & 36.55 \\
\hline $\mathrm{Bw}_{2}$ & $12-27$ & 4.7 & 11.30 & 5.60 & 0.24 & 1.37 & 0.75 & 0.31 & 0.07 & 0.53 & 2.60 & 0.30 & 4.56 & 10.13 & 36.40 \\
\hline C & $27-57$ & 4.8 & 20.30 & 2.98 & 0.60 & 1.46 & 0.72 & 0.28 & 0.08 & 0.31 & 1.80 & 0.80 & 3.99 & 8.49 & 34.84 \\
\hline A & $0-13$ & 4.5 & 105.6 & 13.30 & 0.56 & 3.28 & 1.05 & 0.30 & 0.06 & 0.51 & 2.20 & 0.80 & 4.92 & 21.39 & 39.02 \\
\hline $\mathrm{Bt}_{1}$ & $13-30$ & 4.5 & 21.20 & 7.18 & 0.11 & 1.27 & 0.48 & 0.30 & 0.06 & 0.27 & 4.00 & 0.60 & 5.71 & 18.42 & 19.44 \\
\hline $\mathrm{Bt}_{2}$ & $30-60$ & 4.5 & 14.60 & 5.60 & 0.14 & 1.46 & 0.44 & 0.20 & 0.06 & 0.51 & 4.20 & 0.80 & 6.21 & 15.15 & 19.48 \\
\hline C & $60-90$ & 4.7 & 16.40 & 4.90 & 0.23 & 2.18 & 0.54 & 0.25 & 0.09 & 0.44 & 2.00 & 0.10 & 3.42 & 7.95 & 38.60 \\
\hline Ap & $0-15$ & 4.6 & 27.40 & 14.88 & 0.77 & 4.19 & 1.03 & 0.36 & 0.13 & 0.52 & 2.20 & 0.10 & 4.34 & 14.00 & 47.00 \\
\hline Bw & $15-32$ & 4.6 & 19.20 & 9.80 & 0.71 & 2.19 & 0.59 & 0.45 & 0.99 & 0.48 & 5.00 & 0.60 & 8.11 & 18.86 & 30.95 \\
\hline
\end{tabular}

Table 2. Physical analytical results for the study area

\begin{tabular}{|c|c|c|c|c|c|c|}
\hline \multirow{2}{*}{ Pedon ID } & \multirow{2}{*}{ Horizon ID } & \multirow{2}{*}{$\begin{array}{l}\text { Depth } \\
(\mathrm{cm})\end{array}$} & \multicolumn{3}{|c|}{ Particle size determination } & \multirow{2}{*}{ Texture } \\
\hline & & & Sand $\left(\mathrm{g} \cdot \mathrm{kg}^{-1}\right)$ & Silt $($ g.kg-1) & Clay (g.kg-1) & \\
\hline \multirow{4}{*}{1} & $A$ & $0-10$ & 300 & 490 & 210 & $\mathrm{~L}$ \\
\hline & Bt1 & $10-30$ & 240 & 450 & 310 & $\mathrm{CL}$ \\
\hline & $\mathrm{Bt} 2$ & $30-56$ & 160 & 450 & 390 & $\mathrm{SiCL}$ \\
\hline & C & $56-106$ & 180 & 350 & 470 & C \\
\hline \multirow{4}{*}{2} & $A$ & $0-12$ & 340 & 410 & 250 & $\mathrm{~L}$ \\
\hline & Bw1 & $12-27$ & 280 & 350 & 370 & $\mathrm{CL}$ \\
\hline & Bw2 & $27-57$ & 240 & 310 & 450 & C \\
\hline & C & $57-120$ & 220 & 310 & 470 & C \\
\hline \multirow{4}{*}{3} & $A$ & $0-13$ & 440 & 330 & 230 & $\mathrm{~L}$ \\
\hline & Bt1 & $13-30$ & 400 & 210 & 310 & $\mathrm{CL}$ \\
\hline & $\mathrm{Bt} 2$ & $30-60$ & 360 & 230 & 410 & $C$ \\
\hline & $C$ & 60-90 & 300 & 270 & 430 & C \\
\hline \multirow{2}{*}{4} & $A p$ & $0-15$ & 460 & 230 & 310 & $\mathrm{SCL}$ \\
\hline & $\mathrm{R}$ & $15-32$ & 340 & 230 & 430 & C \\
\hline
\end{tabular}

Texture was sandy loam to clay for pedon 1, loam to clay for pedon 2, loam to clay for pedon 3, sandy clay loam to clay for pedon 4 (Table 2). The high percentage of sand fraction in surface horizon for most pedons and loam in some other could be as a result of parent material (sedimentary) from which the soils were formed (Peter and Umweni, 2020a). Silt fraction ranged from $490 \mathrm{~g} . \mathrm{kg}^{-1}$ to $350 \mathrm{~g} . \mathrm{kg}^{-1}$ in mapping unit $1,410 \mathrm{~g} \cdot \mathrm{kg}^{-1}$ to $310 \mathrm{~g} \cdot \mathrm{kg}^{-1}$ in mapping unit 2, 330 g. kg-1 to 270 g. $\mathrm{kg}^{-1}$ in mapping unit 3 , and 230 g. $\mathrm{kg}^{-1}$ to $230 \mathrm{~g}^{\mathrm{kg}} \mathrm{g}^{-1}$ in mapping unit 4 . The moderate silt content, if not properly managed, could be reduced to 
low level due to leaching in the study area. This is also in agreement with the findings of Peter and Umweni (2020b). Clay fraction of particle size varied from $210 \mathrm{~g} \cdot \mathrm{kg}^{-1}$ to $470 \mathrm{~g} \cdot \mathrm{kg}^{-1}$ in mapping unit 1, 250 g. kg ${ }^{-1}$ to 470 g. $\mathrm{kg}^{-1}$ in mapping unit 2, $230 \mathrm{~g} . \mathrm{kg}^{-1}$ to

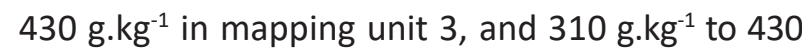

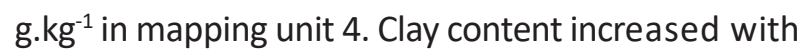
the increase in depth, indicating active eluviation and illuviation processes, which is in agreement with the findings of Tomczyk et al. (2020).

\section{Soil classification}

The data generated from both profile description (morphological description) and laboratory analysis of the soil samples were used to classify the soils according to USDA Soil Taxonomy (Soil Survey Staff, 2014) and locally into series as shown in Table 3.

\section{Land evaluation}

Land suitability evaluation for rubber was done using the guidelines provided by Bhermana et al. (2013), Sys (1985) and Djeaudin et al. (2003). For rubber production, mapping units 1 and 2 occupying 27.4 ha $(27.4 \%)$ were found to be marginally suitable in the area with defect in climate (length of dry months), which is in agreement with Mongkolsawat and Putklang (2010). Mapping unit 3 occupying 38 ha $(38 \%)$ was found to be currently not suitable for

Table 3. Summary of the soil classification for the four mapping units

\begin{tabular}{clccc}
\hline \multirow{2}{*}{ Pedon } & USDA & Series & $\begin{array}{c}\text { Areal extent } \\
\text { (ha) }\end{array}$ & $\begin{array}{c}\text { Areal coverage } \\
\text { (\%) }\end{array}$ \\
\hline 1 & Loamy Isohyperthermic Typic Plinthudult & Origo & 14.2 & 14.2 \\
2 & Loamy Isohyperthermic Ruptic - Ultic - Dystrudept & Origo & 13.2 & 13.2 \\
3 & Loamy Isohyperthermic Typic Plinthudult & Origo & 38.0 & 38.0 \\
4 & Loamy Isohyperthermic Ruptic - Ultic - Dystrudept & Ekiti & 34.7 & 34.7 \\
\hline
\end{tabular}

Table 4. Summary of the soil classification for the four mapping units

\begin{tabular}{clcc}
\hline S/N & Soil mapping unit & Rubber & Cashew \\
\hline 1 & UZ 1 & S3 & S2 \\
2 & UZ 2 & S3 & S2 \\
3 & UZ 3 & N1 & S3 \\
4 & UZ 4 & N1 & S3 \\
\hline
\end{tabular}

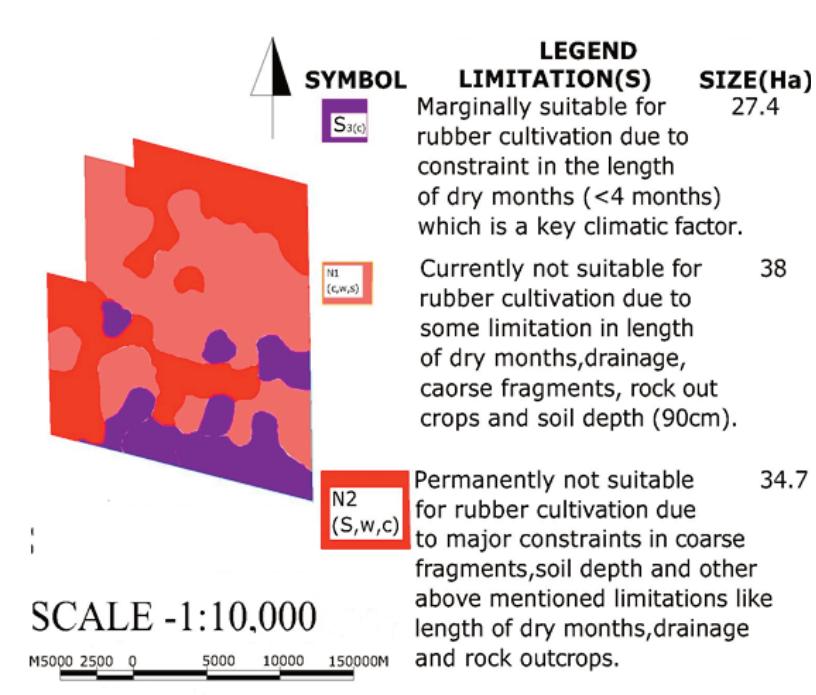

Figure 2. Land suitability map for rubber

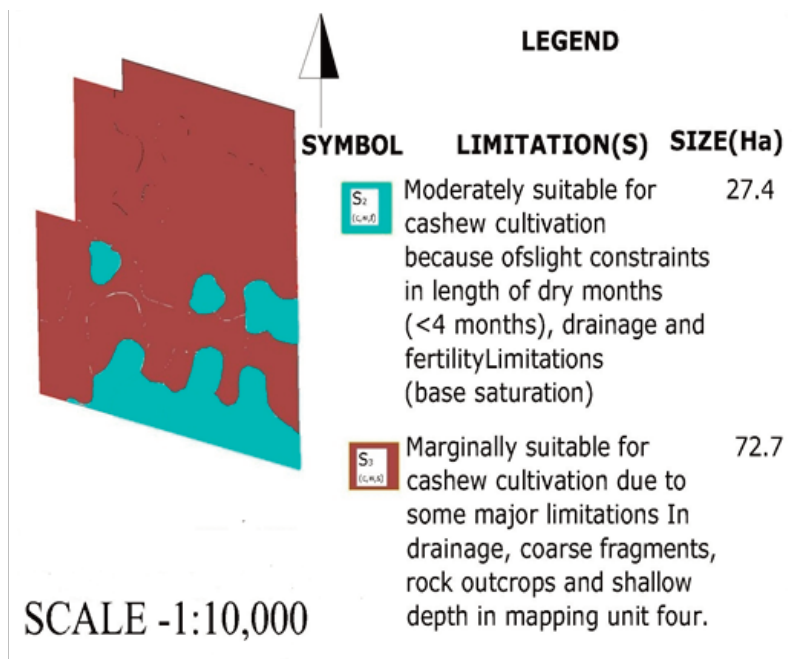

M5000 $2500 \quad 5000 \quad 10000 \quad 150000 M$

Figure 3. Land suitability map for cashew 
rubber production with defects in climate, wetness and soil physical properties (length of dry season, drainage, soil depth, rock outcrops and coarse fragments), which is in agreement with Bhermana et al. (2013). Mapping unit 4 occupying an area of 34.7 ha ( $34.7 \%$ ) was found to be permanently not suitable for rubber production with combined defects as in the above mapping units, as opined by Olowojoba et al. (2016). The climatic condition should be monitored to know when it is best to cultivate. In mapping units 3 and 4, the area could be used for animal husbandry or construction of farm houses for the farmers since the defects of drainage, rock outcrops and soil depths associated with the area cannot be ameliorated easily.

The summary of the suitability of the 100 ha land for rubber production is shown in the soil suitability map (Figure 2). Suitability of cashew was assessed using the guidelines provided by Sys, (1985), Bhermana et al. (2013) and Tyagi (2003). The results showed that mapping units 1 and 2 occupying an area of 27.4 ha were found to be moderately suitable for cashew cultivation with some minor defects, which can be reduced by monitoring the climatic condition and the use of other soil amendments according to Sys (1985). Meanwhile, mapping units 3 and 4 occupying an area of 72.7 ha were found to be marginally suitable for cashew production. The major defects can be monitored to reduce the effects on cashew cultivation (Olowojoba et al., 2016) as shown in Table 4. Figure 3 shows the suitability evaluation map for cashew.

\section{Summary of suitability in all the mapping unit for both rubber and cashew}

The land suitability ranking for both rubber and cashew in all the four pedons is shown in Table 4. From the results of these evaluations, it is obvious that rubber cannot be cultivated unless it is justified economically because of some critical limitations to its production in the area. However, for cashew cultivation, 27.4 ha can be put into production at moderate level. However, with proper management, mapping units 3 and 4 can also be cultivated to cashew since the limitations to its production can be ameliorated and also, cashew can help the sustainable management of the soils in the area.

\section{CONCLUSIONS}

The land evaluated included mapping units 1, 2, 3 and 4 covering an area of approximately 100 ha. Mapping units 1 and 2 covering an area of 27.4 ha (27.4\%) were marginally suitable for rubber but moderately suitable for cashew cultivation, mapping unit 3 covering an area of 38 ha was found to be currently not suitable for rubber but marginally suitable for cashew, and mapping unit 4 covering an area of 34.7 ha was found to be permanently not suitable for rubber cultivation but marginally suitable for cashew cultivation.

Unless there is sufficient economic justification for investment, rubber should not be cultivated in that 100-ha land, but cashew can be cultivated on 27 ha, and prudent management on mapping units 3 and 4 could also be included for cashew cultivation. Thus, the preferred crop for the area under investigation is cashew.

\section{REFERENCES}

Anderson, F. and Ingram, I. (1993). Tropical soil biology and fertility. A hand book of methods. $2^{\text {nd }}$ ed. Wallingford, UK: C.A.B. International, pp. 221.

Behzad, M., Albaji, M., Papan, P., Nasab, S.B., Naseri, A.A., and Bavi, A. (2009). Qualitative evaluation of land suitability for principal crops in the Gargar Region, Khuzestan Province, Southwest Iran. Asian Journal of Plant Sciences, 8(1), pp. 28-34.

Bhermana, A., Sunarminto, B.H., Utami, S., Gunawan, T. (2013). The combination of land resources evaluation approach and GIS application to determine prime commodities for agricultural land use planning at developed area (a case study of Central Kalimatan Province, Indonesia). Journal of Agricultural and Biological Science, 8(12), pp. 771-784.

Bremner, J.M. and Mulvaney, C.S. (1996). Nitrogentotal. In: Page, A.L., Miller, R.H., Keeney, D.R. eds., Methods of Soil Analysis, $2^{\text {nd }}$ ed. Madison, Wisconsin: American Society of Agronomy, Soil Science Society of America, pp 595-624.

Dent, D. and Young, A. (1981). Soil survey and land evaluation. $3^{\text {rd }}$ ed. London, UK: George Allen and Unwin Publishers, pp. 121-132. 
Djaenudin, D., Marwan, H., Subagjo, H., and Hidayat, A. (2003). Petunjuk teknis evaluasi lahan untuk komoditas pertanian. $1^{\text {st }}$ ed. Bogor: Balai Penelitian Tanah, pp. 132.

Food and Agriculture Organization. (1984). Land evaluation for forestry. $2^{\text {nd }}$ ed. FAO Forestry Paper 48. Rome: FAO, pp. 123.

Food and Agriculture Organization (1976). Framework for land evaluation. $4^{\text {th }}$ ed. FAO Soils Bulletin No 32. Rome, Italy: Food and Agriculture Organization, pp 32-54.

Gee, G.W. and Or, G. (2002). Particle size analysis. In: Dane, J.H. and Topp, G.C. eds., Methods of Soil Analysis part 4, Physical Methods. Book series No. 5. Madison, WI: ASA and SSA, pp. 225-293.

Mclean, E.O. (1982). Soil pH and lime requirement. In: Page, A.L. ed., Methods of Soil Analysis Part 2, Chemical and Microbiological Properties. Madison: American Society of Agronomy, Soil Science Society of America, pp. 199-224.

Mongkolsawat, C. and Putklang, W. (2010). An approach for estimating area of rubber plantation: Integrating satellite and physical data over the Northeast Thailand. Proceeding of $31^{\text {st }}$ Asian Conference on Remote Sensing 2010, 2, pp. 1228-1234.

Olowojoba, S.O., Kappo, A.A., Ogbole, J.O., Alaga, A.T., Mohammed, S.O., and Eguaroje, E.O. (2016). Land suitability and evaluation for the production of cassava in Akoko-Edo L.G.A. of Edo State using geo-technology techniques. Greener Journal of Agricultural Sciences, 6(2), pp. 059-068.

Olsen, S.R. and Sommers, L.E. (1982). Phosphorus. In: Methods of Analysis Part 2. $3^{\text {rd }}$ ed. Madison, Winscosin: America Society of Agronomy, pp. 15-72.

Page, A.L., Miller, R.M. and Kenny, D.R. (1982). Methods of soil analysis. No 9, Part 2, Chemical and microbial properties. $2^{\text {nd }}$ ed. Madison, Wisconsin, USA: American Society of Agronomy, pp 102-115.

Peder, A., Margaret, R.G., Herald, S., and Wang, B. (2001). A decision-making tool for land evaluation in the developing countries. [online]. Available at: https://cartogis.org/ docs/proceedings/archive/auto-carto-londonvol-2/pdf/a-decision-making-tool-for-landevaluation.pdf. [Accessed 28 July 2021].

Peter, K.D. and Umweni, A.S. (2021). Evaluation of land suitability for citrus cultivation in Khana
Local Government Area of Rivers State, Southern Nigeria. Ilmu Pertanian (Agricultural Science), 6(1), pp. 1-9.

Peter, K.D. and Umweni, A.S. (2020a). Morphological and physical properties of development from coastal plain sands and alluvium in Khana Local Government Area of Rivers State, Southern Nigeria. African journal of Sustainable Agricultural Development, 1(1), pp. 1-9.

Peter, K.D. and Umweni, A.S. (2020b). Characterization and classification of soils developed from coastal plain sands and alluvium in Khana Local Government Area of Rivers State, Southern Nigeria. Direct Research Journal of Agriculture and Food Science, 8(7), pp. 246-253.

Remison, S.U. (2005). Agriculture as the way. Inaugural Lecture. Ambrose Alli University.

Rossiter, D.G. (2001). Land evaluation processes draft copy. M.Sc Thesis. Cornell University College of Agriculture and Life Science, Department of Soil, Crop and Atmospheric Sciences.

Rossiter, D.G. and Van Wambake, A.R. (1997). Automated land evaluation system ALES Version 4.65 User's Manual. Ithaca: Cornell University, Department of Soil, Crop and Atmospheric Sciences (SCAS) Teaching Series.

Soil Survey Staff. (2014). USDA keys to soil taxonomy. $10^{\text {th }}$ ed. Washington, DC: National Resource Conservation Service, US Dept. of Agriculture, pp. 332.

Sys, C. (1985). Land evaluation part 1,11 and 111. Ghent: State University of Ghent, Belgium International Training Centre for Post Graduate Soil Scientist, pp 221-258.

Tan, K.H. (1996). Soil sampling, preparation and analysis. $4^{\text {th }}$ ed. Madison Avenue, New York: Mercel Dekker Inc. 270, pp 22-48.

Thomas, G.W. (1982). Exchangeable cation. In: Page, A.L. et al. eds., Methods of Soil Analysis. Part 2, Agron. Monograph, 9. $2^{\text {nd }}$ ed. Madison, Wisconsin: American Society of Agronomy and Soil Science Society of America, pp. 159-165.

Tomczyk, A., Sokołowska, Z., and Boguta, P. (2020). Biochar physicochemical properties: pyrolysis temperature and feedstock kind effects. Re. Environ. Sci. Biotechnol., 19, pp. 191-215.

Tyagi, S. (2003). Agricultural land use planning using remote sensing techniques in part of South Goa (India). Proceedings of the $21^{\text {st }}$ International Cartographic Conference, pp. 1254-1259.

Weppa Wanno Farms. (2013). Annual weather reports. pp. 67-95. 